Hal : 22-27

\title{
IMPLEMENTASI MANAJEMEN PENINGKATAN KINERJA GURU PADA MAN HUTAGODANG, KABUPATEN LABUHANBATU SELATAN
}

\author{
AZIDDIN HARAHAP \\ Fakultas Ekonomi dan Bisnis Universitas Labuhan Batu, Sumatera Utara Indonesia \\ Diterima (Bulan 5 Tahun 2020) dan Disetujui (Bulan 7 \&Tahun 2020)
}

\begin{abstract}
ABSTRAK. Tidak dapat dipungkiri bahwa komponen utama pendidikan adalah guru. Peran strategis guru telah menyumbangkan $36 \%$ dalam menciptakan kualitas pendidikan. Meskipun demikian, hingga saat ini masih nampak ke permukaan problematika kinerja guru. Dimulai dari masih banyak di antara guru yang melaksanakan pembelajaran terhadap peserta didik tidak menyiapkan dan mengacu pada silabus dan RPP (Rencana Pelaksanaan Pembelajaran), guru tidak menguasai materi pembelajaran secara luas dan mendalam, proses pembelajaran lebih didominasi oleh guru daripada murid, orientasi pembelajaran yang bersifat kognitif dan mengejar subject matter daripada afektif dan psikomotorik dan aktivitas mengajar guru yang bersifat rutinitas belaka, kering dari nilai-nilai normatif berdasarkan panggilan jiwa, minat, bakat maupun idealismenya. Kesimpulan penelitian ini adalah: lembaga pendidikan Islam MAN Hutagodang, kabupaten Labuhanbatu Selatan telah dikelola dengan baik dengan menerapkan fungsi-fungsi manajemen: perencanaan, pengorganisasian, pelaksanaan/kepemimpinan dan pengawasan. Kelemahan terdapat pada fungsi perencanaan yang tidak disertai dengan rencana biaya, rencana pengawasan/evaluasi dan penanggungjawab program. Pengorganisasian dilakukan dengan menetapkan tupoksi (tugas pokok dan fungsi) guru dan jabatan tambahannya dan struktur organisasi MAN Hutagodang. Pelaksanaan kegiatan peningkatan kinerja guru adalah: Diklat KTSP, Diklat mata pelajaran, Diklat Prajabatan, MGMP dan bimbingan teman sejawat dengan tipe kepemimpinan kepala madrasah bersifat demokratis. Pengawasan kinerja guru dilakukan dengan supervisi kelas.
\end{abstract}

\section{Kata Kunci: Manajemen, Kinerja Guru}

\section{Pendahuluan}

Gejala perkembangan dunia yang merupakan proses alamiah itu bukanlah sesuatu yang hendak dijauhi atau tidak dipedulikan karena memang menghindarinya tidak mungkin bisa dilakukan, maka seorang guru tentunya haruslah bijak dalam menyikapinya dan turut menjadikannya sebagai frame of reference bagi guru profesional dalam sistem pembelajaran. Pada tataran inilah pentingnya kualitas kinerja guru mesti terus ditingkatkan dan diperbaharui, meskipun dalam berbagai kesempatan telah dilaksanakan programprogram pengembangan guru (teacher development) tetapi tetap saja tidak ada satupun metode yang paling ampuh yang dapat menstimulasi pertumbuhan semua guru atau mencapai semua tujuan pengembangan guru. Di samping itu, kita juga mesti berpegang pada postulat "tidak ada satupun aktivitas atau amal manusia yang paling sempurna", yang membuat manusia perlu terus menerus menyempurnakan diri.

Berbagai permasalahan di atas jika ditelusuri penyebabnya secara cermat dalam kerangka manajemen pendidikan, maka kepala madrasah adalah orang yang paling bertanggungjawab terhadap munculnya persoalan itu sekaligus mesti berusaha mencari solusinya. Kepala madrasah juga diharapkan menjadi orang yang pertama dalam suatu lembaga pendidikan yang dapat merespons berbagai perkembangan paradigma pendidikan. Hal ini disebabkan karena posisinya sebagai manajer dan pemimpin yang diserahi tugas oleh pejabat tertentu atau yayasan untuk mengelola lembaga pendidikan dengan baik. Pejabat atau yayasan yang mengangkat seorang guru untuk menduduki posisi kepala madrasah sudah tentu didasarkan atas studi kelayakan bahwa guru tersebut mampu 
menjadi kepala madrasah dan memimpin sebuah lembaga pendidikan. Menjadi tugas dan tanggungjawab kepala madrasahlah untuk membina dan membimbing guru-guru tersebut agar menjadi guru profesional dan berkinerja tinggi.

Dengan mengkaji latar belakang permasalahan di atas, maka penulis merasa tertarik untuk melihat lebih dekat kondisi obyektif implementasi manajemen peningkatkan kinerja guru pada sebuah lembaga pendidikan Islam negeri yang ada di kabupaten Labuhanbatu Selatan yaitu MAN (Madrasah Aliyah Negeri) Hutagodang, kecamatan Sungai Kanan. Alasan pemilihan latar penelitian ini dikarenakan MAN Hutagodang adalah satusatunya Madrasah Aliyah Negeri yang ada di kabupaten Labuhanbatu Selatan yang telah menunjukkan berbagai keberhasilan peserta didiknya dalam berbagai event yang diselenggarakan oleh Departemen Agama kabupaten Labuhanbatu. Keberhasilan tersebut merupakan indikasi kinerja guru yang dimanaj sedemikian rupa oleh kepala madrasah dan unsur pimpinan lainnya.

\section{Metodologi Penelitian}

Metodologi penelitian ini dengan menggunakan pendekatan kualitatif yaitu metode penelitian dengan pendekatan postposivitik (Safitri, Pasaribu, Simamora, \& Lubis, 2019) dengan teknik: wawancara, observasi/pengamatan dan studi dokumentasi. Setelah teknikteknik itu ditempuh dengan analisis data model siklus Miles dan Huberman: pengumpulan data, reduksi data dan penyajian/verifikasi dilakukan pula teknik pemeriksaan keabsahan data, yaitu triangulasi: triangulasi sumber, triangulasi metode dan triangulasi waktu.

Penelitian ini diharapkan dapat menjelaskan mengenai upaya-upaya yang dilakukan oleh Kepala MAN Hutagodang dalam rangka peningkatan kinerja guru, terutama dalam kaitannya dengan fungsi-fungsi manajemen, yaitu perencanaan, pengorganisasian, pelaksanaan dan pengawasan terhadap konteks pembelajaran dan pendidikan.

\section{Pembahasan Hasil Penelitian}

Pada dasarnya perencanaan yang disusun oleh kepala MAN Hutagodang dan beserta unsur pimpinan lainnya dapat dibedakan menjadi 2 rencana, yaitu rencana strategis (renstra) 2009-2014 dan rencana operasional (Renop) 2009-2010.

Perencanaan MAN Hutogodang untuk taraf MAN tingkat kabupetan sudah begitu baik untuk melakukan perubahan pada lima tahun mendatang. Tindakan berorientasi prospektif (memandang jauh ke depan) yang dilakukan oleh kepala MAN: Drs. Pangadilan Ritonga, M.Ag merupakan indikator bahwa kepala MAN Hutagodang ini visioner. Perencanan (planning) yang disusun Kepala Madrasah dengan melibatkan para guru dan komite, berarti MAN Hutagodang telah menerapkan prinsip Manajemen Berbasis Sekolah (MBS), sebagaimana dikemukakan oleh Syaiful Sagala: "MBS adalah sebagai model pengelolaan pendidikan yang mendorong pengambilan keputusan partisipatif dengan melibatkan secara langsung semua warga sekolah, yaitu guru, siswa, karyawan, orangtua murid dan masyarakat". Demikian juga dikatakan oleh Rohiat bahwa salah satu karakteristik Manajemen Berbasis Sekolah (MBS) adalah partisipasi yang tinggi dari warga sekolah dan masyarakat dengan asumsi bahwa semakin tinggi tingkat partisipasi, maka semakin besar rasa memiliki, rasa tanggungjawab dan semakin besar pula tingkat dedikasinya.

Data yang dipaparkan pada identifikasi kondisi saat ini MAN Hutagodang bukanlah hasil rekayasa belaka, tetapi didasarkan atas fakta di lapangan yang peneliti temukan, misalnya dalam paparan kondisi saat ini tentang guru yang sudah memanfaatkan/menggunakan ruang multimedia, peneliti mewawancarai 2 (dua) orang siswa mengatakan bahwa jumlahnya mencapai 9 (sembilan) dari 23 guru, demikian juga guru yang kreatif menyiapkan media pembelajaran yang didesain sendiri (by desain) sebanyak 9 orang pula dari 23 guru. Berarti benar,

Berdasarkan Renstra MAN Hutagodang 2009 - 2014 seperti pada tabel 4.9., perencanaan pengembangan SDM/peningkatan kinerja guru yang paling ditekankan tampaknya adalah peningkatan kedisiplinan guru. Demikian juga mengenai murid, yang juga diutamakan adalah peningkatan kedisiplinannya. Prioritas ini dapat dicermati pada 


\section{Edu Science}

\section{Vol.7, No.1 (2020)}

Hal : 22-27

pencantuman kondisi siswa dan guru mengenai kedisiplinannya masing-masing pada poin a: masih terdapat $10 \%$ siswa yang sering terlambat hadir ke sekolah. Kondisi yang diharapkan pada lima tahun ke depan: tidak ada lagi siswa yang terlambat hadir ke sekolah, sedangkan kondisi yang diharapkan pada satu tahun ke depan: sekitar $8 \%$ siswa yang terlambat hadir sekolah. Mengenai kondisi guru dideskripsikan: masih terdapat $20 \%$ guru yang sering terlambat hadir ke sekolah. Kondisi yang diharapkan pada lima tahun ke depan: tidak ada lagi guru yang terlambat hadir ke sekolah, sedangkan kondisi yang diharapkan satu tahun ke depan tentang kedisiplinan guru adalah $15 \%$ guru yang terlambat hadir ke sekolah. Setelah dilakukan cross check dengan menerapkan triangulasi metode dari dokumentasi ke wawancara, kepala MAN Hutagodang mengatakan bahwa perencanaan yang utama dalam meningkatkan kinerja guru adalah meningkatkan kedisiplinannya: disiplin hadir ke sekolah mulai pukul $07.30 \mathrm{~s} / \mathrm{d} 14.00$ wib bagi PNS dan 15 menit sebelum masuk pelajaran bagi guru honor sudah harus hadir dan juga disiplin masuk dan keluar kelas.

Tidak dapat disangkal bahwa masih banyak sekolah/madrasah dalam menyusun perencanaan tidak menerapkan paradigma ini (perencanaan berdasarkan data yang akurat/analisis kondisi), bahkan lebih banyak lagi lembaga pendidikan Islam yang tidak diurus (dimanej) secara baik. Dengan demikian, berdasarkan data yang telah diparapkan di atas, menurut analisis peneliti, langkah-langkah yang ditempuh oleh MAN Hutagodang dalam menyusun Renstra adalah sebagai berikut:

1) Analisis atau identifikasi kondisi pendidikan saat ini, 2) Analisis kondisi pendidikan yang diharapkan pada lima tahun ke depan, 3)Menentukan kesenjangan antara situasi pendidikan saat ini dan yang diharapkan lima tahun ke depan, 4)Merumuskan visi sekolah,5)Merumuskan misi, 6) Menentukan strategi pelaksanaan, dan 7)Menentukan hasil yang mesti dicapai.

Langkah-langkah yang ditempuh oleh kepala MAN Hutagodang dalam menyusun Renstra di atas, menurut peneliti telah mencapai kebenaran $70 \%$. Hal ini didasarkan pendapat Rohiat .

Rencana Operasional (Renop) menurut peneliti tidak berbeda dengan rencana jangka pendek karena sama-sama menjangkau waktu dalam 1 (satu) tahun dan merupakan penjabaran dari Renstra. Artinya, Renop disusun berdasarkan Renstra dan tidak boleh menyimpang dari Renstra sehingga antara Renstra dan Renop harus terkait dan terdapat benang merah.

Mencermati Rencana Operasional (Renop) MAN Hutagodang di atas, langkah penetapan tujuan/sasaran dari program-program pengembangan SDM dan peningkatan kinerja guru sudah tepat. Sebagaimana dikatakan oleh Syafaruddin bahwa dalam perencanaan ada tujuan khusus dan tujuan tersebut secara khusus sungguh-sungguh dituliskan dan diperoleh semua anggota organisasi, tampak telah mengarah pada pencapaian Standar Kompetensi Pendidik: kompetensi pedagogik, kompetensi profesional, kompetensi sosial dan kompetensi profesional. Rencana pelaksanaan Diklat KTSP, Diklat mata pelajaran, MGMP dan supervisi kelas adalah kegiatan-kegiatan yang akan meningkatkan kompetensi pedagogik dan profesional. Sosialisasi rencana program dan bimbingan teman sejawat akan meningkatkan kompetensi sosial dan pelatihan kecerdasan emosional spritual (ESQ) akan meningkatkan kompetensi kepribadian guru.

Kelemahan pada fungsi perencanan ini adalah tidak/belum dibuatnya rencana biaya, rencana pemantauan/pengawasan dan penanggungjawab program/kegiatan, padahal ketiga langkah itu sangat berpengaruh terhadap lancar tidaknya pelaksanaan program. Biaya (budget) dalam sebuah organisasi boleh dikatakan sebagai ruhnya organisasi karena tidak ada program yang dapat dilaksanakan tanpa biaya dan itu pasti membutuhkan pengelolaan yang baik agar perencanaan finansial dapat dipergunakan untuk kepentingan pengembangan madrasah secara efektif dan efisien. Perencanaan pengawasan (supervisi) merupakan kegiatan menempatkan siapa dan kapan rencana tersebut akan dilaksanakan harus dirumuskan secara jelas dalam kurun waktu satu tahun dengan disertai 


\section{Edu Science}

Vol.7, No.1 (2020)

Hal : 22-27

penanggungjawab setiap kegiatan baik oleh perorangan atau kelompok berdasarkan SK kepala madrasah.

Penentuan tugas pokok dan fungsi (tupoksi) personil MAN Hutagodang sebagai langkah pengorganisasian merupakan tindakan yang tepat untuk memberikan tugas dan tanggungjawab dan mungkin juga pendelegasian wewenang untuk melakukan tindakantindakan tertentu sesuai dengan ranah tupoksinya. Tindakan penentuan tupoksi ini dalam istilah populernya adalah membagi-bagi kerja.

Hal ini sudah tentu didasari oleh prinsip-prinsip dan azas-azas penilaian yang ada dalam sistem evaluasi. Wewenang yang dimiliki oleh guru ini tampaknya sudah dimaklumi oleh kepala MAN Hutagodang, sehingga kepala tidak mencampuri urusan penilaian ini dan akibatnya terdapat $3 \%$ siswa pada tahun pelajaran 2008/2009 tidak naik kelas/tidak lulus. Apalagi wewenang seorang kepala madrasah, seperti wewenangnya untuk memberikan sanksi berupa peringatan maupun pemberhentian terhadap guru yang indisipliner, wewenangnya untuk mengelola keuangan berupa pengadaan media pembelajaran, pemberian tambahan honor maupun insentif terhadap guru.

seorang pemimpin tidak boleh hanya pandai membagi-bagi kerja sebagai langkah pengorganisasian tetapi juga mesti bijak dalam membagi-bagi finansial (keuntungan). Pada tataran terakhir ini tampaknya terdapat kelemahan kepala MAN Hutagodang karena dalam perencanaan belum dialokasikan penambahan gaji bagi guru honor dari Rp 23.000,- per jam pelajaran. Padahal kinerja dituntut sama dengan guru PNS, guru PNS memperoleh gaji yang besar ditambah lagi dengan tunjangan lauk-pauk Rp 15.000,- per hari.

Pemberian keteladanan kedisiplinan merupakan langkah yang tepat dilakukan oleh seorang kepala MAN Hutagodang untuk memotivasi guru-gurunya, tata usaha maupun siswa dalam menunjukkan prestasi kerja (kinerja). Dari penjelasan kepala MAN Hutagodang (Drs. Mugan Harahap) yang menyatakan bahwa ia membiasakan diri secara konsisten memberikan contoh tersirat pengertian bahwa yang dimaksud keteladanan bukan hanya mencakup kedisiplinan tetapi dalam kerangka yang lebih luas. Termasuk di antaranya keteladanan dalam ketaatan beribadah, keteladanan kemampuan mengajar (profesionalitas), kepedulian sosial dan sesuainya kata dengan perbuatan (komitmen). Kepribadian yang disebut terakhir ini menjadi taruhan bagi kepala madrasah setelah ia melakukan bimbingan terhadap guru maupun siswa. Jangan sampai seorang kepala justru menjadi bagian dari masalah karena tidak sesuai antara kata dan perbuatannya. Misalnya, ketika seorang kepala membimbing guru untuk menyusun silabus dan RPP yang baik, maka yang pertama sekali yang mampu menyusunnya adalah kepala madrasah. Sungguh ironis, jika kepala madrasah memberikan bimbingan kepada guru supaya menjadi guru profesional dengan indikasi menyiapkan perangkat pembelajaran dan mengacu pada perangkat pembelajaran itu ketika mengajar, menerapkan strategi dan metode pembelajaran yang menyenangkan, menyiapkan media pembelajaran, tetapi ia sendiri tidak mampu melakukan itu, maka kepala madrasah tipe ini akan menjadi bagian dari masalah.

Dengan demikian, menurut analisis peneliti kepala MAN Hutagodang yang saat ini bertugas tipe kepemimpinannya demokratis dengan gaya mengutamakan pelaksanaan tugas, sedangkan kepala madrasah sebelumnya menerapkan tipe kepemimpinan demokratis dengan gaya mengutamakan kerjasama.

Tindakan melakukan kegiatan supervisi kelas yang dilakukan oleh kepala MAN Hutagodang adalah tindakan yang tepat karena kegiatan itu menjadi tugas dan tanggungjawab kepala madrasah sesuai dengan tupoksi dan sesuai pula dengan fungsinya sebagai supervisor. Justifikasi ini merujuk pada penjelasan Mulyasa bahwa kedudukan kepala sekolah sebagai supervisor dalam pembelajaran dapat dilakukan melalui kegiatan kunjungan/observasi kelas. Dalam hal ini, jenis kunjungan/observasi kelas dapat bermacam-macam: kunjungan kelas tanpa diberitahu, kunjungan kelas dengan diberitahu terlebih dahulu dan kunjungan kelas atas undangan guru. Selain kegiatan supervisi semacam itu, bisa juga dikembangan kegiatan supervisi lainnya, misalnya intervisitasi 


\section{Edu Science}

\section{Vol.7, No.1 (2020)}

Hal : 22-27

(saling mengunjungi kelas antarguru), menyeleksi berbagai sumber materi untuk mengajar dan menilai diri sendiri dengan instrumen penilaian yang jelas.

Kegiatan supervisi atau pengawasan jalannya pembelajaran ini sangat penting dilakukan untuk mencegah terjadinya berbagai penyimpangan dari perencanaan madrasah dan yang lebih penting lagi agar tidak terjadi penyimpangan dari standar proses pembelajaran. Standar proses pembelajaran telah diamanahkan dalam Peraturan Pemerintah No. 19 Tahun 2005 tentang Standar Nasional Pendidikan sebagai berikut:

Proses pembelajaran pada satuan pendidikan diselenggarakan secara interaktif, inspiratif, menyenangkan, menantang, memotivasi peserta didik untuk berpartisipasi aktif serta memberi ruang yang cukup bagi prakarsa, kreativitas, dan kemandirian sesuai dengan bakat, minat, dan perkembangan fisik serta psikologis peserta didik.

Kepala madrasah yang tidak melakukan kegiatan supervisi terhadap guru-guru akan mengakibatkan terjadinya pembiasaan perilaku yang buruk terjadi pada guru-gurunya. Bagaimana seorang kepala madrasah dapat mengetahui pelaksanaan pembelajaran di kelas dilaksanakan secara efektif, tercapai tujuan pembelajarannya: Standar Kompetensi (SK), Kompetensi Dasar (KD) dan indikator-indikatornya, seperti tercantum dalam silabus dan RPP jika tidak dilakukan supervisi kelas. Faktor tidak adanya kegiatan supervisi inilah yang menyebabkan buruknya kinerja guru itu menjadi tanggungjawab kepala madrasah. Dalam kaitan fungsi kepala madrasah sebagai manajer, jika ia tidak mampu menjadi supervisor ia bisa meminta bantuan pada supervisor fungsional atau guru-guru senior yang mungkin lebih tahu mengenai pelaksanaan supervisi. Persis sama dengan siswa yang tidak dapat mencapai tujuan pembelajaran sebanyak $40 \%$ dalam satu kelas, maka yang patut dipersalahkan adalah guru karena guru belum optimal dalam melaksanakan proses pembelajaran sesuai standar.

\section{Kesimpulan}

MAN Hutagodang, kabupaten Labuhanbatu Selatan telah dikelola dengan baik dengan indikator tersusunnya perencanaan pengembangan madrasah, khususnya pula perencanaan peningkatan kinerja guru. Jenis perencanaan yang dibuat oleh MAN Hutagodang berupa perencanaan strategis (Renstra) 2009 - 2014 dan rencana operasional (Renop) tahun 2009/2010. Meskipun langkah-langkah dalam penyusunan perencanaanperencanaan di atas belumlah sempurna.

Pengorganisasian yang dilaksanakan MAN Hutagodang adalah dengan menetapkan tugas-tugas pokok dan fungsi (Tupoksi) guru dan jabatan-jabatan tambahan guru. Selain itu penjelasan tentang hubungan atau interaksi antar semua personil pendidikan yang ditunjukkan dengan adanya struktur organisasi yang jelas di MAN Hutagodang juga merupakan metode yang dilakukan untuk mengorganisir MAN Hutagodang dalam rangka sinergi mencapai tujuan pendidikan yang telah direncanakan.

Kegiatan yang sudah dilaksanakan dalam upaya peningkatan kinerja guru adalah: Diklat KTSP, Diklat mata pelajaran, Diklat Prajabatan bagi CPNS, Musyawarah Guru Mata Pelajaran (MGMP), bimbingan teman sejawat, pelaksanaan supervisi kelas dan pelaksanaan hari-hari besar Islam. Kepemimpinan MAN Hutagodang adalah tipe kepemimpinan demokratis dengan indikator melibatkan semua sumber daya manusia yang ada dalam menyusun perencanaan dan pengambilan keputusan (decision making).

Untuk menjamin terlaksananya semua perencanaan dan tujuan pembelajaran yang sudah ditetapkan dilakukan pengawasan terhadap guru dalam bentuk supervisi kelas. Bagi guru yang menunjukkan kinerja yang tinggi diberikan reward (hadiah/ganjaran)dan guru yang buruk kinerjanya diberikan punisment (sanksi/hukuman). 


\section{Edu Science}

Vol.7, No.1 (2020)

Hal : 22-27

ISSN : 2303-355X

\section{DAFTAR PUSTAKA}

AECT. The Defenition of Educational Terminology. Washington: AECT, 1977.

Aly, Hery Noer dan S, H. Munzier. Watak Pendidikan Islam. Jakarta: Friska Agung Insani, 2000.

Daulay, Haidar Putra. Dinamika Pendidikan Islam. Bandung: Citapustaka Media, 2004

Asari, Hasan. Etika Akademis Dalam Islam. Yogyakarta: Tiara Wacana, 2008.

Azizy, A. Qodri A. Pendidikan (Agama) Untuk Membangun Etika Sosial. Semarang: Aneka IImu, 2003.

Safitri, I., Pasaribu, R., Simamora, S., \& Lubis, K. (2019). The Effectiveness of Android Application as a Student Aid Tool in Understanding Physics Project Assignments. Jurnal Pendidikan IPA Indonesia , 512-520.

Syafaruddin Manajemen Lembaga Pendidikan, Jakarta: Ciputat Press, 2005

Beach, D.M. dan Judy, R. Supervisory Leadership: Focus on Instruction. Massacusetts: Allyn Bacon, 2000.

Buchori, Mochtar. Pendidikan dan Pembangunan. Jakarta: IKIP Muhammadiyah Jakarta Press, 2004.

al-Bukhari, Abu 'Abd. Allah Muhammad bin Isma'il. Sahih al-Bukhari. Beirut: Dar al-Fikr, t.t.

Burton, W.H. The Guidance of Learning Activities. New York: Appleton Century. Inc, 1944.

Cooper, Robert K. dan Sawaf, Ayman. Executive EQ: Kecerdasan Emosional dalam Kepemimpinan dan Organisasi. Jakarta: PT. Gramedia Pustaka Utama, 1998. 